GHILD BEHAVIOUR PROBLEMS 
to Katherine and John 


\title{
CHILD BEHAVIOUR PROBLEMS
}

\section{AN EMPIRICAL APPROACH TO MANAGEMENT}

Roger McAuley MB, DPM, MRC Psych.

Consultant Child Psychiatrist

Royal Belfast Hospital for Sick Children

Belfast, $\mathcal{N}$. Ireland

Patricia McAuley BA, Dip. Soc. Studies, Dip. Soc. Work

\author{
Senior Social Worker
}

Eastern Area Health and Social Services Board

Down District, Downpatrick, $\mathcal{N}$. Ireland

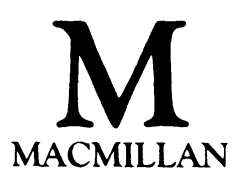


Roger McAuley and Patricia McAuley 1977

Softcover reprint of the hardcover 1st edition 1977 978-0-333-21687-3

All rights reserved. No reproduction, copy or transmission of this publication may be made without written permission.

No paragraph of this publication may be reproduced, copied or transmitted save with written permission or in accordance with the provisions of the Copyright Act 1956 (as amended).

Any person who does any unauthorised act in relation to this publication may be liable to criminal prosecution and civil claims for damages.

First published 1977

Reprinted 1985

Published by

Higher and Further Education Division

MACMILLAN PUBLISHERS LTD

Houndmills, Basingstoke, Hampshire RG21 2XS

and London

Companies and representatives

throughout the world

ISBN 978-0-333-21688-0 ISBN 978-1-349-15827-0 (eBook)

DOI 10.1007/978-1-349-15827-0 


\section{Contents}

Foreword vi vi

Acknowledgements viii

I Introduction I

Part I Assessment

2 The Case History I3

3 Introduction to Observation 28

4 Methods of Recording Behaviour 35

5 The Therapist as Observer 44

6 The Parent and Child as Observers $\quad 5^{6}$

Part II Planning $\quad 63$

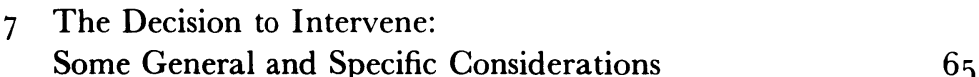

8 Theoretical Considerations in Planning 82

Part III Intervention 95

9 Simple Contingency Management 97

Io Points Systems 114

I I Bargaining and Contracting 136

12 Delinquency and Non-Accidental Injury:

Some Aspects of Aetiology and Management $\quad$ I 50

I 3 School-Refusal, Enuresis and Encopresis:

Some Aspects of Aetiology and Management $\quad$ I 72

I4 Failure: Some Theoretical and Practical Considerations 195

Appendix A: Selected Textbooks $\quad 215$

Appendix B: Selected Journal Articles 219

Glossary of Selected Behavioural Terms 223

References $\quad 227$

Index $\quad 235$ 


\section{Foreword}

Efforts to help psychologically troubled children have changed drastically over the past 20 years. The prevailing tendency to bring these children into direct contact with highly trained professionals has shifted to an alternative focus on the children's natural caretakers. In this latter strategy the caretakers are viewed as therapists, rather than having this role fulfilled by professionals. The professional's role has changed from therapist to consultant-one who 're-educates' the parents and schoolteachers of troubled children. This re-education notion is based on the assumption that caretaker and child are locked into problem relationships with one another. By teaching the caretakers some new ways of responding to their children, it is reasonable to expect that the children's deviant behaviours should change. In essence, the problem relationships should disappear; both caretaker and child should develop mutually supporting therapeutic behaviours.

This new trend in child therapy has been given the popular label applied behaviour analysis (ABA). The ABA strategy argues that deviant behaviour is developed and maintained by its short term stimulus associations. The discovery of these associations, usually dispensed by parents and teachers of the troubled child, should permit a systematic shifting in how the stimuli operate. Given that the caretakers can be convinced to alter their stimulus output for the child, it should be possible to develop new and desirable child behaviours.

Like any therapeutic strategy, ABA has a theoretical model connected with its application. Most ABA consultants rely on reinforcement theory to guide their assessment and intervention work. 'Learning' in an operant sense makes up the bulwark of the ABA consultant's view of how stimulus contingencies produce and maintain a child's problem behaviour. The theory also guides the consultant's teaching efforts to modify these contingencies.

The happy marriage between applied behaviour analysis and reinforcement theory has prospered, but there have also been recent episodes of domestic strife. Therapeutic changes in child behaviour 
have not always been sustained: the application of reinforcement prescribed treatment techniques does not always work; there is increasing evidence that successful intervention may be accompanied by side effects not understood on the basis of reinforcement principles. The overall implications of these difficulties must be considered by any proponent of applied behaviour analysis.

The McAuleys present a text responsive to these new developments in applied behaviour analysis. While prior texts have given readers a standard, rather simplistic view of the ABA helping process, these authors give us an updated version of complexities inherent in this strategy. Their version of how one intervenes with the troubled child is by no means a panacea for the field. They present the problems of assessment and treatment honestly, and they outline a most reasonable way of dealing with these constraints.

University of Tennessee, Knoxville, October 1976

ROBERT G. WAHLER 


\section{Acknowledgements}

Many people contributed in one way or another to this book. The authors wish to thank John Barcroft and Bob Wahler who read preliminary versions of the manuscript and made valuable suggestions. We are further indebted to Bob Wahler for writing the Foreword. We are grateful to Jerry Harbison for comments on selected chapters and to Jim Quinn who first encouraged our interest in behaviour modification.

The Royal Victoria Hospital, Belfast and the Eastern Area Health and Social Services Board assisted the first author in that the former awarded him a research fellowship, during which time much of the clinical work described was completed and ideas formulated, and the latter seconded him to the USA, where he was able to consolidate his knowledge and conduct useful discussions with friends such as Bob Nay and Denis Moore.

Colleagues in the Department of Child Psychiatry, Royal Belfast Hospital for Sick Children, also deserve special thanks: William Nelson for providing cases; Kathy McKeown, Anna Fyfe, Bruce Stewart and Anne Hutton who were the principal therapists in some of the case studies presented in the text; and the staff at Lissue Hospital who nursed the in-patients.

Geraldine Duffy and Gertrude Heron typed preliminary versions of the manuscript and Twy Miller typed a remarkably rapid final draft. We would also like to thank John Morrow for arranging photocopying facilities for the reproduction of the final draft.

The main contributors to the book are, however, the parents and children. We have preserved their anonymity by altering names and other details of identification.

Although this book is a collaborative effort, the contribution of each author was clearly defined. The first author contributed his clinical experience in child psychiatry and a thorough working knowledge of the practice of behaviour modification with children, and its associated literature. The second author helped in the formulation and writing of the text, and viewed the venture as a professional helper who had hitherto been uninitiated in the mysteries of behaviour modification. 